\title{
Assessment of Heavy Metals and Total Hydrocarbon Content in Tilapia (Oreochromis Aureus) from Ibaka River, Nigeria
}

\author{
Ekpenyong*, Effiong Okokon \\ Department of Chemistry, College of Education (affiliated to University of Uyo) Afaha Nsit, P.M.B 1015 Etinan, \\ Akwa Ibom State, Nigeria. \\ *Corresponding Author: Ekpenyong, Department of Chemistry, College of Education (affiliated to \\ University of Uyo) Afaha Nsit, P.M.B 1015 Etinan, Akwa Ibom State, Nigeria.
}

\begin{abstract}
This study was carried out to assess the concentrations of $\mathrm{Pb}, \mathrm{Fe}, \mathrm{Cd}, \mathrm{V}, \mathrm{Hg}$ and Total Hydrocarbon Content (THC) in Tilapia (oreochromis aureus) from Ibaka river during 2018 wet season. The fish specimens (60) collected were processed and analyzed for Heavy metals and Total Hydrocarbon content using atomic absorption spectrophotemetry (AAS) and GC - FID respectively. The Chronic Daily Intake (CDI) and Hazard Quotient (HQ) of heavy metals concentrations were evaluated using standard equations. Generally, level of metal concentrations $(\mathrm{mg} / \mathrm{kg})$ forFe $(0.69+0.04-0.98+0.12), \mathrm{Pb}(0.49+0.10-0.92+$ 0.14), $\mathrm{Ni}(0.47+0.01-0.95+0.34), \mathrm{V}(0.01+0.00-0.0+0.01), \mathrm{Cd}(1.027+0.35-1.092+0.45), \mathrm{Hg}$ $(0.01+0.00-0.01+0.00)$ in the fish far exceeded the WHO and FAO maximum and permissible limits. Only the Hazard Quotient (HQ) of Cd (1.046 - 1.091) in all species of tilapia was greater than 1 (Cd>1) and this may pose serious health problems to consumers of fishes from Ibaka river. The mean level of total hydrocarbon content $\left(\right.$ THC) $(0.952+0.21-1.065+t 0.25) p_{m}$ in tilapia specie, were persistent and significant $(P>0.05)$ higher between locations especially from the month of August to October, 2018. Thus tilapia specie from Ibaka river for now may not be safe for human consumption. The Government should as of a matter of urgent importance and national concern ban chemical fishing and put a stop to indiscriminate disposal of organic and inorganic pollutants into Ibaka environment.
\end{abstract}

\section{INTRODUCTION}

Tilapia species may face severe extinction in Ibaka River in future probably due to metal and oil pollutions. These type of pollutions hold a major potential hazard to surface water and fish and consequently to all living things. According to Davies et al (1983), heavy metals pollution can alter quality of water bodies by increasing the odour, colour, $\mathrm{pH}, \mathrm{BOD}$ and $\mathrm{P}_{4}{ }^{3-}$ and make them unfit for drinking. Heavy metals on the other hand can disrupt natural quality of fish and fish tissue (Abuet al 2012), increase fish disease and mortality (Saxena et al 2018), influence physiological rates of fish reproduction (Korisiakpere and Ubogu, 2001).

The results of heavy metals bioaccumulation in various species of tilapia fish - Heterotis niloticus, orechromis niloticus, clarius niloticus, orechromis aureus reporled within Niger Delta show the pollution level as manifesting higher presence of $\mathrm{Ni}, \mathrm{Pb}, \mathrm{Hg}, \mathrm{Cd}, \mathrm{V}, \mathrm{Fe}, \mathrm{Zn}, \mathrm{As}$ (Udosen 2014, Chinda etal 2005, Alinor 2009, Akpanyung et.al 2016, Edem et.al 2009, Ayotundeetal 2012). These results indicated the possibility that deleterious impacts could evolve after a long period of consumption. Heavy metal normally degradesasthey are persistent, stable, toxic and non-biodegradable. Except $\mathrm{Ni}$, $\mathrm{Fe}, \mathrm{Zn}$, others such as $\mathrm{Hg}, \mathrm{Cd}, \mathrm{Pb}$ have no known biological functions in living organism whatsoever, thus in fish they exhibit extreme toxicity at low concentration (Hu, 2002), and can cause health problems and death. Construction firms, boatyard, commercial trading posts, naval base and modern seafood market dotted along Ibaka river bank may be the main source of metal generating wastes that tend to impact negatively on Ibaka river environment. Waste from these sources can bi-concentrate in seafood species, and in fishes to levels in excess of public health standard and can present a health hazard to those eating them.

Oil pollution of Ibaka river may have occurred through oil spillage, crude oil production, cleaning of storage tanks. Total Hydrocarbon Content (THC) consists of a mixture of Aliphatic Hydrocarbon (AH) and Poly Aromatic Hydrocarbon (PAH). Aliphatic Hydrocarbon contains phenol, hexene, toluene, xylene, naphthalene etc. (ATSDR, 1999) while Poly Aromatic Hydrocarbon has 21 
components out of which 7 of them are classified carcinogenic. These are benz(0)anthracene, benz (0) pyrene Bap, Indo [1,2,3, - Cd] Pyrene (IND) dibenz (a, b), anthiacene [DBahA] with BAP as always highest in causing cancer risk. Some of the exposure pathways to cancer risk are through inhalation, fish ingestion and food ingestion. PAH and phenols are one of the ubiquitous sets of chemicals which result from crude oil and abound in the environment. Adult fish may experience reduced growth, reproductive impairment when exposed to crude oil. After all oil related activities leads to elevated levels of total hydrocarbon in seafood from Bonny estuary (Amadi and Braide 2003, Benson etal 2001), whereas volatile components like benzene, toluene and other light hydrocarbon are capable of triggering pneumonia, damaged red blood cells, suppress immune system, strain liver, spleen and kidney (Okeogbu, 2006).

Monitoring of Total Hydrocarbon Content and Heavy Metal in tilapia from Ibaka river has never been reported. Thus continuous monitoring and assessment of both inorganic and organic pollutants in tilapia fish from Ibaka river form the basis of this work.

\section{STUDY AREA}

Ibaka river lies from latitude $4038^{\prime} 0$ " $\mathrm{N}$ to $4042^{\prime} 0$ " $\mathrm{N}$ and longitude $8018^{\prime} 0$ " $\mathrm{E}$ to $8010^{\prime}$ ' 0" $\mathrm{E}$ coordinates within Mbo Local Government Area (Fig I) of Akwa Ibom State. It borders vertically the eastern flank of Cross River and occupies a considerable length of littoral portion of Atlantic Ocean far beyond the low water mark.

The area is characterized by dry season (November - April) and wet season (May - October). Along the coast, the rainfall is heavy above $3000 \mathrm{~mm}$ than along the fringe that records $2000 \mathrm{~mm}$. The area experiences an average temperature which varies between $260 \mathrm{c}$ and $280 \mathrm{c}$ with a maximum temperature of $30.3 \mathrm{oc}$ and a minimum of about $4.1 \mathrm{oc}$. The relative humidity varies between $75 \%$ and $85 \%$ while salinity fluctuates significantly. Ibaka river has a natural depth of (11-16m), water current velocity $(6.2-9.5 \mathrm{cmsec}-1)$ and water transparency $(30.30-52.81 \mathrm{~cm})$ as reported by Umar $(2012)$. Ibaka river also has a long stretch that opens into gulf or Guinea and the water is brackish and highly saline. Ibaka river contributes significantly to food availability and security, trade and improved living standard as well as preservation of biodiversity. It is a good nursery ground for cultivation of tilapia and breeding of different fish and sea food species for fishermen.

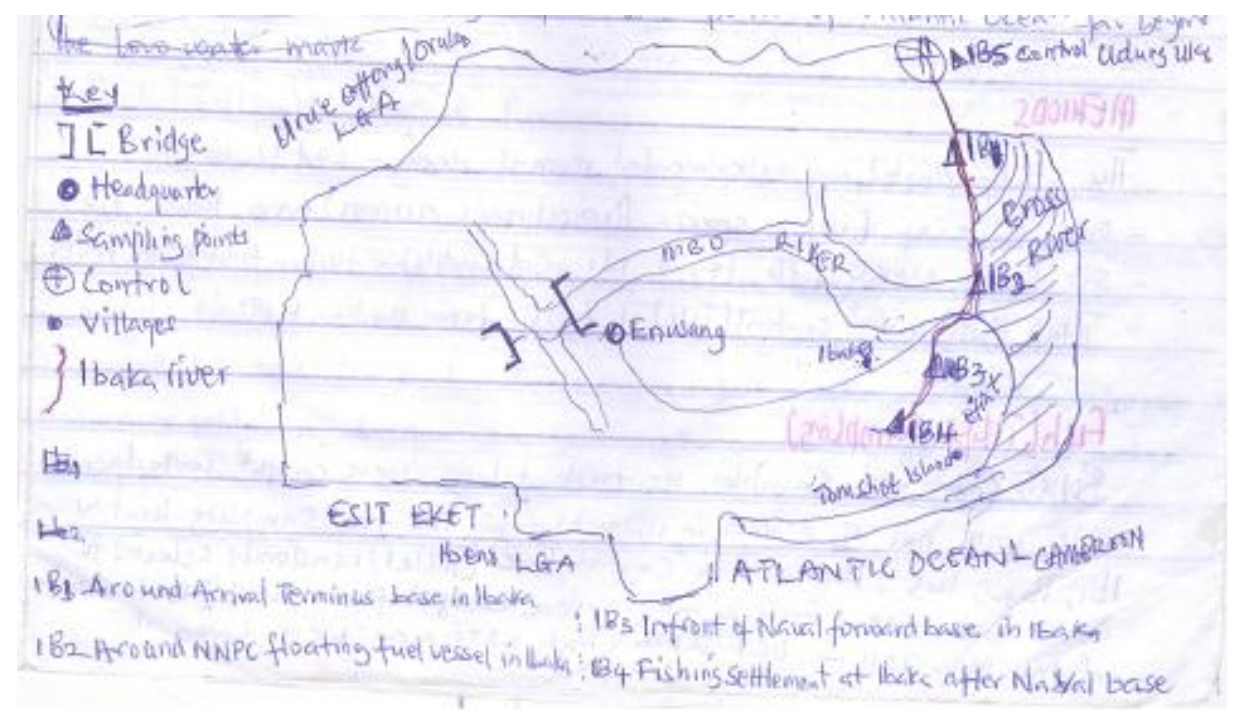

Fig1. Showing Sampling Locations

Table1. Sampling Locations and Their Coordinates on Ibaka River for Fish Samples

\begin{tabular}{|c|c|c|c|c|c|}
\hline Locations & Code & Samples & $\begin{array}{c}\text { Sampling } \\
\text { Coordinates }\end{array}$ & $\begin{array}{l}\text { Parameter } \\
\text { Measured }\end{array}$ & Human Activities \\
\hline $\begin{array}{l}\text { Around arrival } \\
\text { terminus base in } \\
\text { Ibaka. }\end{array}$ & $\mathrm{IB}_{1}$ & Tilipia & $\begin{array}{c}\text { No. } 4^{\circ} 3909.2^{\prime \prime} \\
\text { E } 008^{\circ} 18,53.5^{\prime}\end{array}$ & Heavy metal/THC & $\begin{array}{l}\text { Dumpsites, fuels } \\
\text { stations, abattoirboat and } \\
\text { oil operating companies. }\end{array}$ \\
\hline $\begin{array}{c}\text { Around NNPC } \\
\text { floating fuel vessel } \\
\text { in Ibaka }\end{array}$ & $\mathrm{IB}_{2}$ & Tilipia & $\begin{array}{l}\text { N } 04 \text { 39.04.7”' } \\
\text { E } 008 \text { 19.23.7” }\end{array}$ & Heavy metal/THC & $\begin{array}{l}\text { Chemical fishing, fuel } \\
\text { supply. }\end{array}$ \\
\hline
\end{tabular}


Assessment of Heavy Metals and Total Hydrocarbon Content in Tilapia (Oreochromis Aureus) from Ibaka River, Nigeria

\begin{tabular}{|c|c|c|c|c|c|}
\hline $\begin{array}{c}\text { In front of naval } \\
\text { forward base in } \\
\text { Ibaka. }\end{array}$ & $\mathrm{IB}_{3}$ & Tilipia & $\begin{array}{c}\mathrm{N} 04 \text { 43.23.9” } \\
\text { E 008 16.56 22” }\end{array}$ & Heavy metal/THC & $\begin{array}{c}\text { Naval, and maritime } \\
\text { operations, lumbering } \\
\text { activities. }\end{array}$ \\
\hline $\begin{array}{c}\text { Fishing settlement } \\
\text { immediately } \\
\text { afternaval base. }\end{array}$ & $\mathrm{IB}_{4}$ & Tilipia & $\begin{array}{c}\mathrm{N} 043913.2 \% \\
\text { E } 00819509 \%\end{array}$ & Heavy metal/THC & $\begin{array}{c}\text { Boat construction, } \\
\text { chemical fishing, sand } \\
\text { excavation. }\end{array}$ \\
\hline Nung Uko. & $\mathrm{IB}_{5}$ (control) & Tilipia & $\begin{array}{c}\text { N 0E 37 13.5” } \\
\text { E 008 22 40.8” }\end{array}$ & Heavy metal/THC & No fishing, calm water. \\
\hline
\end{tabular}

\section{MATERIAL AND MethodS}

\subsection{Materials}

The instruments include; 6890 Angilant Gas Chromatograph Induction Detector and a computerized inductively coupled plasma spectrometer (ICP) Optima 300 Permer Elmer). All reagents were of Analar grade.

\subsection{Methods}

The study adopted an experimental research design and focused on;

- One type of tilapia specie (Oreochromis aureus) from Ibaka river

- Six heavy metals $(\mathrm{Pb}, \mathrm{Fe}, \mathrm{V}, \mathrm{Ni}, \mathrm{Cd}$ and $\mathrm{Hg}$ ) in tilapia from Ibaka river.

- Total Hydrocarbon content (THC) of tilapia from Ibaka river.

\subsubsection{Fish (Tilapia Sampling)}

Sixty (60) samples of fresh tilapia were caught with locally made wire net of $2.5 \mathrm{~mm}$ in diameter from the four sampling locations IB1, IB2, IB3, IB4 and a control IB5 (Table 1) randomly selected to cover Ibaka river. Fish samples were caught from Ibaka in wet season from May 2018October 2018. Fish specimen were taken in polythene bags and stored in a deep freezer at $10 \mathrm{oC}$ in a fishery store for proper identification. The length of tilapia species varies between 20.4 and $29.5 \mathrm{~cm}$ SL and mass from 210 and $340 \mathrm{~g}$ were measured and weighed respectively prior to treatment and analysis.

\subsubsection{Fish (Tilapia Samples) Treatment}

The tilapia samples were allowed to defrost and the whole body chopped with a clean stainless steel knife on a wooden cutting board and mixed to homogeneity. The samples were dried to constant weight in an oven at $105 \mathrm{oC}$ and crushed in clean mortar with piston.For metal extraction quantities $5 \mathrm{~g}$ each of whole fish samples were digested using $0.02 \mathrm{MHNO} 3$ and $\mathrm{HCl}$ in the ratio 1:3 (aqua regia) in a fumed cupboard at $80 \mathrm{oC}$. For total hydrocarbon extraction about $5 \mathrm{~g}$ of each dried and ground sample spiked with squalene and C32 - alkane were serially extracted with methyl isobutyl ketone (Analargrade). The solvent was allowed to settle and later centrifuged and decanted. The extracts were concentrated on a rotary evaporator and maintained at $20 \mathrm{oC}$ to volume of about $5 \mathrm{~mL}$.

\subsubsection{Fish (Tilapia) Laboratory Analysis}

\begin{tabular}{|c|c|c|}
\hline Parameter & Standard Analytical Procedures & $\begin{array}{c}\text { Author/Bodies Describing } \\
\text { the Procedures }\end{array}$ \\
\hline Heavy metals & $\begin{array}{c}\text { Digestion, Extraction, Filtration Atomic Absorption } \\
\text { Spectrophtometry using Computerised inductively } \\
\text { coupled plasma spectrometer (ICP) optima 3000 } \\
\text { (Perkins Elmer) model. }\end{array}$ & $\begin{array}{c}\text { ASTM (1964), } \\
\text { AOAC (1996) }\end{array}$ \\
\hline $\begin{array}{c}\text { Total Hydrocarbon } \\
\text { content }\end{array}$ & 6890 Gas Chromatograph Flame Induction Detector \\
(GC - FID). & ASTM (1964) \\
\hline
\end{tabular}

Heavy metals $\mathrm{Pb}, \mathrm{Fe}, \mathrm{V}, \mathrm{Ni}, \mathrm{Cd}$ and $\mathrm{Hg}$ in whole tilapia specimens were analyzed using a computerized inductively coupled plasma spectrometer (ICP) optima 3000 (Perkins Elmer) model while Total Hydrocarbon Content were analyzed using 6890 Angilant Gas Chromatograph induction detector (GC - FID): Concentrations of Total Hydrocarbons Contents were quantified relative to the total peaks and were converted to weights using hydrocarbon standard calibration. Blank analyses were carried out and all the values, were computed for corrections. 
Assessment of Heavy Metals and Total Hydrocarbon Content in Tilapia (Oreochromis Aureus) from Ibaka River, Nigeria

\subsubsection{Fish (Tilapia) Statistical Analysis}

The data obtained were collected and subjected to mean, standard deviation and one way analysis of variance. The ANOVA and Duncan's Multiple Range Test (DMRT) was used to assess whether heavy metals concentrations varied significantly between locations, while the Chronic Daily Intake (CDI) and the Hazard Quotient (HQ) of heavy metals in tilapia species were evaluated using standard equations.

\section{RESUlts}

In (Table 2) the results of heavy metals presence in tilapia shows average bioaccumulation levels as $\mathrm{Fe}(0.83+0.21 \mathrm{mg} / \mathrm{kg}), \mathrm{Pb}(0.7+0.19 \mathrm{mg} / \mathrm{kg}), \mathrm{V}(0.1+0.00 \mathrm{mg} / \mathrm{kg}) \mathrm{Ni}(0.67+0.15 \mathrm{mg} / \mathrm{kg}), \mathrm{Cd}(0.59$ $+0.12 \mathrm{mg} / \mathrm{kg})$ and $\mathrm{Hg}(0.01+0.00 \mathrm{mg} / \mathrm{kg})$.

Table2. Average concentration of Heavy Metals $(\mathrm{mg} / \mathrm{kg})$ in Tilapia from Ibaka River caught in Wet Season at all locations.

\begin{tabular}{|c|c|c|c|c|c|c|}
\hline $\begin{array}{c}\text { Sampling } \\
\text { Periods }\end{array}$ & $\begin{array}{c}\text { Iron } \\
\text { M+-SD }\end{array}$ & $\begin{array}{c}\text { Lead } \\
\text { M+-SD }\end{array}$ & $\begin{array}{c}\text { Cadmium } \\
\text { M+-SD }\end{array}$ & $\begin{array}{c}\text { Vanadium } \\
\text { M+-SD }\end{array}$ & $\begin{array}{l}\text { Nickel } \\
\text { M+-SD }\end{array}$ & $\begin{array}{c}\text { Mercury } \\
\text { M+-SD }\end{array}$ \\
\hline April 2018 & $0.77+0.20$ & $0.51+0.10$ & $0.59+0.10$ & $<0.0+0.00$ & $0.62+0.20$ & $<0.01+0.00$ \\
\hline May 2018 & $0.69+0.20$ & $0.49+0.10$ & $0.3 \overline{7+} 0.05$ & $<0.0 \overline{1+0} 0.00$ & $0.55 \overline{+0} .20$ & $<0.01 \overline{+0} .00$ \\
\hline June 2018 & $0.7 \overline{4+0} .20$ & $0.6 \overline{8+0.10}$ & $0.4 \overline{6+}+0.04$ & $<0.01 \overline{0.00}$ & $0.47 \overline{+0} .10$ & $<0.01 \overline{+0} .00$ \\
\hline July $2 \mathrm{a} 018$ & $0.70+0.20$ & $0.72+0.20$ & $0.5 \overline{9+} 0.20$ & $<0.01+\overline{0.00}$ & $0.62 \overline{+0} .20$ & $<0.01 \overline{+0.00}$ \\
\hline August 2016 & $0.97+0.30$ & $0.8 \overline{4+0} .30$ & $0.5 \overline{54}+0.20$ & $0.01+\overline{0.00}$ & $0.71 \overline{+0} .20$ & $0.01+\overline{0} .00$ \\
\hline September 2018 & $0.9 \overline{6+0.30}$ & $0.8 \overline{1+0.30}$ & $0.7 \overline{8+} 0.30$ & $0.0 \overline{1+0} 0.00$ & $0.74 \overline{+0} .20$ & $0.02 \overline{+0.00}$ \\
\hline October 2018 & $0.9 \overline{8+0} 0.30$ & $0.9 \overline{2+0} .35$ & $0.9 \overline{2+} 0.30$ & $0.0 \overline{1+0} 0.00$ & $0.95 \overline{+0} .30$ & $0.03 \overline{+0} 0.00$ \\
\hline Mean & $0.83 \overline{+0} .21$ & $0.71 \overline{+0.19}$ & $0.5 \overline{9+} 0.12$ & $0.0 \overline{1+0.00}$ & $0.67 \overline{+0} .15$ & $0.01+0.00$ \\
\hline $\begin{array}{c}\text { IB }_{5}(\text { Control }) \\
\text { max. Limit }\end{array}$ & $0.2 \overline{8+0.04}$ & $0.0 \overline{4+0.01}$ & $0.4 \overline{2+} 0.08$ & $<\overline{0.0} 1$ & $0.25 \overline{+0} .01$ & $<\overline{0.0} 1$ \\
\hline $\begin{array}{c}\text { WHO max. } \\
\text { Limit (2011) }\end{array}$ & 0.30 & & 0.2 & & 0.4 & $<0.01$ \\
\hline FAO (2007) & & 0.05 & 0.5 & $<0.01$ & 0.4 & $<0.01$ \\
\hline
\end{tabular}

Average values are of triple determinations $+S D, N=3$

Table3. Risk Assessment values of Cd in Tilipia from Ibaka River in the Wet Season between locations

\begin{tabular}{|lccccc|}
\hline SAMPLING PERIOD & \multicolumn{1}{l|}{ LOCATIONS } \\
\hline $\mathrm{IB}_{1} \mathrm{IB}_{2} \mathrm{IB}_{3} \mathrm{IB}_{4} \mathrm{IB}_{5}$ (control) & \multicolumn{5}{l}{} \\
\hline Early wet season (2018).HQ & 1.081 & 1.059 & 1.080 & 1.046 & 0.523 \\
\hline Late wet season (2018).HQ & 1.091 & 1.065 & 1.087 & 1.051 & 0.525 \\
\hline
\end{tabular}

Note: $\mathrm{HQ}>1$ pose high risk, $\mathrm{HQ}<1$ pose little or no risk (Yi et al 2011).

Standard Equations used are:

$\mathrm{CDI}=\frac{\mathrm{EF} \times \mathrm{ED} \times \mathrm{FIR} \times \mathrm{C} \times 10^{-3}}{\mathrm{EW} \times \mathrm{AT}}$

$\mathrm{HQ}=\underline{\mathrm{CDI}}(2) \quad \mathrm{RFD}$

Where CDI = Chronic Daily Intake

$\mathrm{HQ}=$ Hazard Quotient.

$\mathrm{RFD}=$ Oral Reference Dosage of Cd (mg/kg / day) $=5 \times 10^{4}($ USEPA, 2005).

$\mathrm{EF}=$ Exposure frequency, Ingestion rate $=\mathrm{IR}$

$\mathrm{ED}=$ Exposure duration Concentration $=\mathrm{C}$

$\mathrm{BIO}=$ Average body height, $\mathrm{AT}=$ Average time for non-carcinogens.

$\mathrm{HQ}$ for $\mathrm{Fe}, \mathrm{Pb}, \mathrm{V}, \mathrm{Ni}$ and $\mathrm{Hg}$ calculated were all less than 1 and so posed little or no threat, but the standard equations showed that only Cd recorded Hazard Quotient greater than 1 i.e HQ>1 for all species of tilapia (Table 3).

TABLE4.Concentrations $\left(P^{p m}\right)$ of Total Hydrocarbon Content (Thc) in Tilapia Fish from Ibaka River Caught in Wet Season 2018.

\begin{tabular}{|c|c|c|c|c|c|}
\hline \multicolumn{7}{c}{ SAMPLING } & \multicolumn{6}{c|}{ LOCATIONS } \\
\hline Periods & $\mathbf{I B}_{1}$ & $\mathbf{I B}_{\mathbf{2}}$ & $\mathbf{I B}_{3}$ & $\mathbf{I B}_{\mathbf{4}}$ & $\mathbf{I B}_{\mathbf{5}}$ (Control) \\
\hline April 2018 & $1.046+\underline{0.24}$ & $0.964+\underline{0.20}$ & $0.953+\underline{0.15}$ & $1.041+\underline{0.20}$ & $0.001+\underline{0.000}$ \\
\hline
\end{tabular}


Assessment of Heavy Metals and Total Hydrocarbon Content in Tilapia (Oreochromis Aureus) from Ibaka River, Nigeria

\begin{tabular}{|c|c|c|c|c|c|}
\hline May 2018 & $1.045+0.22$ & $0.963+0.20$ & $0.950+0.20$ & $1.040+0.25$ & $0.003+0.001$ \\
\hline June 2018 & $1.065+\overline{0} .24$ & $0.961+\overline{0.17}$ & $0.941+\overline{0.15}$ & $1.062+\overline{0.30}$ & $0.005+\overline{0.001}$ \\
\hline July 2018 & $1.042+\overline{0.20}$ & $0.958+\overline{0.15}$ & $0.944+\overline{0.20}$ & $1.038+\overline{0.18}$ & $0.003+0.001$ \\
\hline August 2018 & $1.081+0 \overline{0.025}$ & $0.976+\overline{0.16}$ & $0.965+\overline{0.25}$ & $1.074+\overline{0.20}$ & $0.004+\overline{0.002}$ \\
\hline Sept. 2018 & $1.087+\overline{0.30}$ & $0.969+\overline{0.18}$ & $0.954+\overline{0.18}$ & $1.076+\overline{0.2} 8$ & $0.009+\overline{0.003}$ \\
\hline Oct. 2018 & $1.091+\overline{0.45}$ & $0.972+\overline{0.19}$ & $0.959+\overline{0.16}$ & $1.082+\overline{0.35}$ & $0.009+\overline{0.003}$ \\
\hline Mean & $1.065+\overline{0.25}$ & $0.966+\overline{0.17}$ & $0.952+\overline{0.2} 1$ & $1.059+\overline{0.2} 0$ & $0.006+\overline{0.002}$ \\
\hline WHO $0.01\left(\mathrm{PP}^{\mathrm{m}}\right)$ (2011). & $0.0 \overline{1}$ & 0.01 & $0.01^{-}$ & $0.01^{\circ}$ & $0.0 \overline{1}$ \\
\hline
\end{tabular}

Average values of triple determinations $+S D, N=3$.

The total Hydrocarbon content in the tilapia specie were high and showed significant levels from August 2018 October 2018 at $\mathrm{IB}_{1}$ and $\mathrm{IB}_{2}$ locations (Table 4).

\section{DISCUSSION}

The present study shows that tilapia (Oreachromis aureus) metal bioaccumulation preferred $\mathrm{Pb}, \mathrm{Fe}$ and $\mathrm{Cd}$ (Table2). Their concentrations in the tilapia species are significantly ( $>0.05)$ higher than the values recorded for $\mathrm{V}, \mathrm{Ni}$ and $\mathrm{Hg}$. Pb accumulates most significantly as Lead nitrate (Oladimeji and Offem, 1999) while Cd even as a non - essential heavy metal is potentially toxic to most fish, wildlife particularly fresh water organisms (Eisher, 1985). The source of high level of Fe may arise from corrosion of skunked vessels or boats in the river. Another source could be from allothonous materials from offshore. The highest concentration recorded for $\mathrm{V}$, Niand $\mathrm{Hg}$ were $(0.01,0.95$ and .01$) \mathrm{mg} / \mathrm{kg}$ respectively. The little presence of $\mathrm{Hg}$ in fish may have come from additive effects of $\mathrm{Hg}$ in water while oil spillage is the main source of $\mathrm{Pb}$ and $\mathrm{V}$. The significant level of $\mathrm{Pb}, \mathrm{Fe}$ and $\mathrm{Cd}$ in tilapia from the month of August to October 2018 could be traced to the domestic effluent and proximity of the Nigerian National Petroleum Corporation (NNPC) floating fuel vessel and the nearby on-shone oil facilities at Unygenge community. This observation agrees with the reports of Olajire and Oderinde (1993) that oil effluent is the main source of Cd.

Comparatively the metal pollution concentration declined drastically from the month of July to April 2018 at all locations especially at the control (Table 2). The comparison of the overall metal concentrations with WHO maximum permission limits shows that tilapia fish species are polluted. The study agrees with earlier work reported by Akpanyung (2006) for tilapia from Ifiayong river and by Edemetal (2005)for tilapia from Henshaw Town Beach in Calaber, Nigeria.However the values are lower than similar metals reported by Abidal et al (2009) for fishes from Madivala lake in India and for fishes from vial river system in Egypt as reported by Crafford and Avanant (2006). Also the Hazard Quotient (HQ) values (1.046 - 1.091) recorded (table 3) are significantly higher. Considering the carcinogenic, mutagenic nature of $\mathrm{Cd}$, tilapia and other fishes may not be same for $\mathrm{Cd}$ consumption. However this result is consistent with Amirah etal (2003) work in human health risk concentration of metal pollution through consumption of fish.The mean level of Total Hydrocarbon Contents $(0.952+0.21-1.065+0.25) \mathrm{PP}^{\mathrm{m}}$ in the tilapia species investigated (Table 4$)$ when compared with WHO recommended concentration of $0.01 \mathrm{mg} / \mathrm{L}$ (Jack etal 2005) where high.The elevated hydrocarbon contents at locations $\mathrm{IB}_{1}(1.042+0.20-1.091+0.45) \mathrm{PP}^{\mathrm{m}}$ and $\mathrm{IB}_{3}(0.941+0.15-$ $0.959+0.16) \mathrm{PP}^{\mathrm{m}}$ may be due to leak and spills that have occurred during ferrying of engine and gun boats across Ibaka river, usage of generators used for powering saw and fuelling woods at $\mathrm{IB}_{4}(0.958$ $+0.15-0.972+0.19) \mathrm{PP}^{\mathrm{m}}$. Some high level $(\mathrm{THC})$ also noticed at $\mathrm{IB}_{2}(1.038+0.18-10.82+0.35)$ $\mathrm{PP}^{\mathrm{m}}$ may be due to leak from storage tanks and leaks from NNPC floating vessel.

\section{CONCLUSION}

From the study tilapia fish (oreuchromis aureus) from Ibaka river is a metal and oil contamination pathway that could affect human health. The detection of excessive $\mathrm{Fe}, \mathrm{Cd}, \mathrm{Pb}$ and persistence of high level of hydrocarbon in tilapia species from Ibaka River above WHO (2011) maximum limitsis an indication of short and long term chronic accumulation of these pollutants. Thus tilapia fish species from Ibaka River were unsafe for consumption. Government should therefore enact and enforce necessary policies to continually check reckless release of metals effluents and spillage of oil into Ibaka environment. 


\section{REFERENCES}

[1] Abidal B, Harikrisma, S, Kfanulla K.Abidal (2009). Analysis of Heavy metals in fish, water and sediments samples of Iradivalla lakes of Banglore Kamatakai International Journal of Chemical Technology and ResearchCDEN. USA, IJCROO ISSN: 0974-42902:245-249.

[2] Abu, T. A. H, Suman, M. Didarul, A.C, Abu, R.m and Mizanur, R (2012). Bioaccumulation of some heavy metals in fish (separator Hamilton, 1822) sediment and water of Dhaleshwari River in dry season. Bangladesh Journal, 2012, 40 (1): 147-153.

[3] Akpanyang, E. O, Udoudo, M. E, Ekam, I M and Anozie, N. O (2006) Levels of heavy metals in fish obtained from two fishing sites in Akwa Ibom State Nigeria.African Journal of Environment Science and Technology, 24:123-128.

[4] Alinor, I. J. (2009). Bioaccumulation of elemental toxicants of periwinkle and crab from Ibeno River CSN Book of proceedings of $30^{\text {th }}$ Annual Conference of Chemical Society of Nig. (2009) held in Abuja, pp37-40.

[5] Amadi, E.N and Braide SA (2003). Distribution of petroleum hydrocarbon straight degraders around petroleum related facilities in a mangrove swamp of the Niger Delta. Journal of Nigerian Environmental Society, 1 (2) $181-192$.

[6] Association of Official Analytical Chemist (AOAC), (1996). Official method of water and seafood analysis $\left(13^{\text {th }}\right.$ edi) washington DC pp $684-686$.

[7] American Society for Testing and Materials (ASTM), (1964), ASTM Publication Philadelphia PP88 - 94.

[8] American Society for Testing and Materials (ASTM), (1964)American Society of Testing and Materials (ASTDR), (1999). Toxicolgical profile of Aliphatic Hydrocarbon US Department of Health and Human Services. Public Health Service Centre for Diseases Control,Altanta G. A,203 - 93 - 0606.

[9] Amirah M. Afiza A, Fiazal W, Nurliyana M. and Laili s (2003): Human Risk Assessment of Metél Contamination through consumption. Journal of Environmental Pollution and Human Health 1 (2): 7783.

[10] Ayotunde E. O, Offem, B O and Ada, F.B (2012). Assessment of heavy metal profile of water, sediment and fresh water catfish, chrysichihys nigrodigitatus (eeped 1802) of Cross River, Cross River State, Nigeria. International Review Biotropica (International Journal). Tropical Biology ISSN - 0034 - 7744; 60:3.

[11] Benson, N U, Essien J.P, Williams A.B, Ebong G.A (2007) Petroleum Hydrocarbon Accumulation Potential of shellfishes from Littoral Waters of the Bight of Bonny, Niger Delta, Nigeria Research Journal of Environmental Sciences 1 (1), 11-19, ISSN 1819-3412of Academic Journals Inc USA.

[12] Chinda, A, C and Braide A.S (2005) Cadmium and Lead Concentrations in fish species of brakish wetland/Upper Bonny Estuary, Niger Delta. Journal of Nigerian Environmental Society (JNES), 1 (3): 399 - 405.

[13] Crafford, D. and, Avanant A. (2006) Bioaccumulation of non-essential trace metals in tissue and organs of claris gariepinus (sharptooth catfish) from the vial rivers system, South Africa.Strontium, Aluminum Lead and Nickle food Chemistry, 101; $120-125$.

[14] Davies, CA and Benett, BG (1983) "Exposure Commitment Assessment of Environmental Pollutants", University of London Monitoring Assessment and Research Centre, London (MARC Report, 3 (30).

[15] Edem, C A, Osabor, B, Iniama G, Elume, R and Eke, J (2009), Distribution of heavy metals in bones, gills, livers and muscles of tilapia (Orechromis miloticus) from Henshaw Town beach market in Calabar Nigeria Journal of Nutrition, 8 (8): 1209 - 1211.

[16] Eisher, R. (1985), Cadmium hazards to fish wildlife and invertebrates: a Synoptic review, US fish and wildlife services. Biological Reproduction, $85(1,2)$ Washington D.C.

[17] Food and Agriculture Organisaiton of the United Nation (FAO), (2007) Compilation of legal limits forhazardous substances in fish and fishery product food and Agricultural Organization, Fishery Circular, 464:5-100.

[18] Hu, H (2002). Human Health and heavy metals exposure in: Life Support. The Environmental and Human Health, Michael Mccally(ed) MIT Press.

[19] JackI.R, Fu G.K, Feka rurhobo, Igwelk, Okorosaye O. (2005) Determination of some Marine Organisms from some towns within the Rivers State ofNigeria. Journal of Applied Environmental Management, 9; 59-61.

[20] Kori - Siakpee, D, and Ubogu, E. (2008) - Sub - lethal haematological effects of Zinc on the fresh water fish. Heteroclarius Sp. (Osterichthyes: Claride) African Journal of Biotechnology, 7 (12): 2068 - 2013.

[21] Okeagbu (2006). The Environmental and Social Impact of Petroleum and Natural Gas Exploitation in Nigeria. Journal of Third World Studies, 23, PP199 - 200.

[22] Oladimeji A.A and Offem, B.O (1989) Toxicity of Lead to Clarias Lazera, Orechromis nicolitus, Chironomus tatans and Benacus Sp. water, air, soil pollution. 44:191-201.

[23] Olajire,A.A and Oderinde,R.A. (1993). Trace metals in Nigeria crude oils and their heavy end distillates. Bulletin of the chemical society of Japan, 66 (20), $630-632$. 
[24] Saxena, M, Saxena J, Kaurk (2008) Effect of heavy metal pollution of water on response of fish lumphoeytes to mitogenic stimulation. The Internet Journal of Veterinary Medicine, 15 (2); 13-15.

[25] Udosen, E D, Benson N. U, Essien, J. P (2007) Trends in Heavy metals and Total Hydrocarbon Burdens in Stubbs creek, a Tributary of Qua Iboe estuary, Nigeria Trends in Applied Sciences Research 2 (4) 312 3192007 ISSN 1819 - 3579.

[26] Udosen, E. D, Offiong N. O. AlaladeI. G (2014). Human Health Risk Assessment of trace metals due to dietary intake of edible fish species collected from Enyong Creek, Itu - Nigeria C.S.N Proceedings of the $37^{\text {th }}$ Annual International Conference of the Chemical Society of Nigeria held in Uyo. Env $204-231$.

[27] Umar, M (2012) Ibom Industrial City Complex (11cc). Former Minister ofTransport, Nigeria, Comments on Ibaka deep seaport reported in Daily times editorial pp2, Monday $2^{\text {nd }}$ February 2012.

[28] World Health Organization (WHO), 2011. Environmental Health Criteria Heavy metals. 108, Nickel International Programme on Chemical Safety World Health Organization.

Citation: Ekpenyong, Effiong Okokon, "Assessment of Heavy Metals and Total Hydrocarbon Content in Tilapia (Oreochromis Aureus) from Ibaka River, Nigeria”, International Journal of Advanced Research in Chemical Science, vol. 6, no. 9, p. 28-34, 2019. DOI: http://dx.doi.org/10.20431/2349-0403.0609004

Copyright: (C) 2019 Authors. This is an open-access article distributed under the terms of the Creative Commons Attribution License, which permits unrestricted use, distribution, and reproduction in any medium, provided the original author and source are credited. 